\title{
New insights into the lithostratigraphy and paleogeography of the Messinian Kasterlee Formation from the analysis of a temporary outcrop
}

\author{
JASPER VERHAEGEN ${ }^{*}$, LANDER FREDERICKX ${ }^{2}$, MARCO SCHILTZ ${ }^{3}$
}

\author{
${ }^{1}$ VPO, Planning Bureau for the Environment and Spatial Development, Department of Environment, Flemish Government, Koning \\ Albert II-laan 20, 1000 Brussels, Belgium; jasper.verhaegen@vlaanderen.be. \\ ${ }^{2}$ Belgian Nuclear Research Centre (SCK•CEN), Department of Environment, Health and Safety, Boeretang 200, $2400 \mathrm{Mol}$, Belgium. \\ ${ }^{3}$ Samsuffit BVBA, Eggelstraat 8, 2530 Boechout, Belgium. \\ * corresponding author.
}

ABSTRACT. Previous studies have shown that the Kasterlee Formation occurs as far south as the hilltops of Heist-op-den-Berg and Beerzel in the south of the province of Antwerp. In fragmentary outcrops on these hills, a clear threefold subdivision can be recognized. In the current study, a large temporary outcrop on the Heist-op-den-Berg hill was studied, providing a unique view into the smallscale vertical and lateral variations in the Kasterlee Formation. Based on field observations, grain size analyses and mineralogy, the characteristics of the three units could be clearly defined. Cone penetration test logs show that these units can also be traced further north in the basin. As the three units can be easily identified based on the parameters provided in this paper and as they occur over a wide area, it is proposed to introduce them as formal members of the clayey Kasterlee unit. The observations made in this outcrop also allowed to refine the paleogeographic model of the Kasterlee Formation, with deposition of sand-clay alternations in restricted lagoons, separated from the marine environment by a coastal barrier, during an overall regression. Coastal barrier deposits are found in the south and northwest, but in the northeast only deposition in restricted lagoons occurred.

KEYWORDS: granulometry, grain size, mineralogy, CPT logs, southern North Sea Basin, Campine.

\section{Introduction}

Heist-op-den-Berg is located in Belgium at the transition from the Antwerp Campine area, characterized by a mostly flat topography, to the Hageland area, with its characteristic elongated Hageland hills. The Hageland hills are mostly made up of the Diest Formation, often with iron sandstone beds at their tops due to the oxidation of glauconite. As Heist-op-den-Berg is not far north of the Hageland area, the hill, together with the nearby Beerzel hill, has often been considered a northern outlier. As such, and because of the distance $(11 \mathrm{~km})$ to the Kasterlee Formation subcrop area further to the north, the sediments on top of the Heist-op-den-Berg hill were included in the Diest Formation in the mapping survey by Schiltz et al. (1993). Early on, however, it was already recognized that the top sediments at Heist-op-den-Berg may rather belong to the Kasterlee Formation, at that time named 'Casterlien', as a top facies within the Diest Formation, characterized by a decreased glauconite content and the presence of clay laminae (Van den Broeck, 1882; Gulinck, 1963). As a more clayey facies is often considered to also occur in the top of the Diest Formation (Vandenberghe et al., 2020 , this volume) this argument was not sufficient to decide on the presence of the Kasterlee Formation on top of the hill. More recently, Fobe (1995) again argued that the sediments on top of the Heist-op-den-Berg hill belong to the Kasterlee Formation based on sedimentological analyses of samples from a temporary outcrop near the top of the hill and several smaller roadside outcrops. This stratigraphic interpretation was confirmed by Verhaegen et al. (2014) who could definitively assign the sediments to the Kasterlee Formation based on the recognition of a dispersed gravel at the base of the contested sediments at the Heist-op-den-Berg and Beerzel hills which strongly resembles the gravel at the base of the Kasterlee Formation in Olen (Louwye et al., 2007), at the southern end of the continuous Kasterlee Formation to the north of Heistop-den-Berg.

Due to the demolition of the old school which stood on top of the Heist-op-den-Berg hill and the construction works for a new apartment complex, a large temporary outcrop became available in the spring and summer of 2019 which provided a unique exposure of the Kasterlee Formation sediments (added to the database of the subsurface of Flanders, www.dov.vlaanderen.be, with code TO-20190617). In contrast to the fragmentary observations from small outcrops in Verhaegen et al. (2014), continuous vertical and lateral observations could be made in this outcrop, providing more detailed insight into the internal structure of these sediments and their depositional history. In this paper, the field observations are presented, accompanied by pictures, which will serve as a reference documentation of these sediments. Detailed sampling was done across a vertical transect from the top of the Diest Formation to the top of the Kasterlee Formation. These samples were analyzed for grain size distribution and mineralogical composition. Coupled with information from CPT (cone penetration test) logs, the data are interpreted in terms of stratigraphy in correlation with the offshore basin to the north and in terms of depositional environment.

\section{Geological setting}

The outcrop is situated on top of the Heist-op-den-Berg hill, right next to the small sunken lane along which fragmentary observations were made in Verhaegen et al. (2014) (DOV code: TO-20140919) (Fig. 1). Heist-op-den-Berg is located in the south of the Campine area and just to the north of the Hageland area, along the northern edge of the geological London-Brabant Massif.

Following the publication of Verhaegen et al. (2014), the top sediments of the hill were included in the Messinian Kasterlee Formation (Louwye et al., 2007) in the G3Dv2 and recent G3Dv3 3D geological models of the Flemish subsurface, published by Databank Ondergrond Vlaanderen (DOV) (Matthijs et al., 2013; Deckers et al., 2019). The contact between the Diest and Kasterlee Formations observed in the outcrop along the sunken lane on top of the hill does not align perfectly with the presently modelled contact (Fig. 1). This is the result of the single core description of uncertain quality used to define the base of this contact at Heistop-den-Berg and Beerzel (Deckers, pers. comm.). At the base of the described section, the Tortonian Diest Formation occurs. Based on Verhaegen et al. (2014), it can be distinguished from the overlying Kasterlee Formation by its coarser grain size (mode $\sim 375 \mu \mathrm{m})$ and higher glauconite content $(>40 \%)$, giving rise to a dark green color. The Diest Formation in Heist-op-den-Berg is located at the southern extent of the Campine Diest sand, the D1 facies (Adriaens, 2015), near the outcrop of the Hageland Diest sand to the south. The Kasterlee Formation can be subdivided into three units: a lower Hallaar unit, a middle Beerzel unit and an upper Heist-op-den-Berg unit, introduced as unofficial members by Fobe (1995). The Hallaar unit contains a dispersed base gravel of rounded and flattened flint pebbles. The sediment consists of brown-green bimodal sand (modes $\sim 200$ and $650 \mu \mathrm{m}$ ) with glauconite $(>10 \%)$ reworked from the underlying Diest Formation and a significant clay content. The interpretation of reworking is based on the bimodal grain size distribution, the upwards decreasing content of slightly oxidized glauconite in this unit, and the similar grain size distribution of glauconite in the Hallaar unit compared to the Diest Formation in contrast to the differing grain size distribution of the rest fraction (Verhaegen et al., 2014). In the Beerzel unit, the sand is well sorted and fine grained (mode $\sim 200 \mu \mathrm{m}$ ) and the glauconite content strongly 


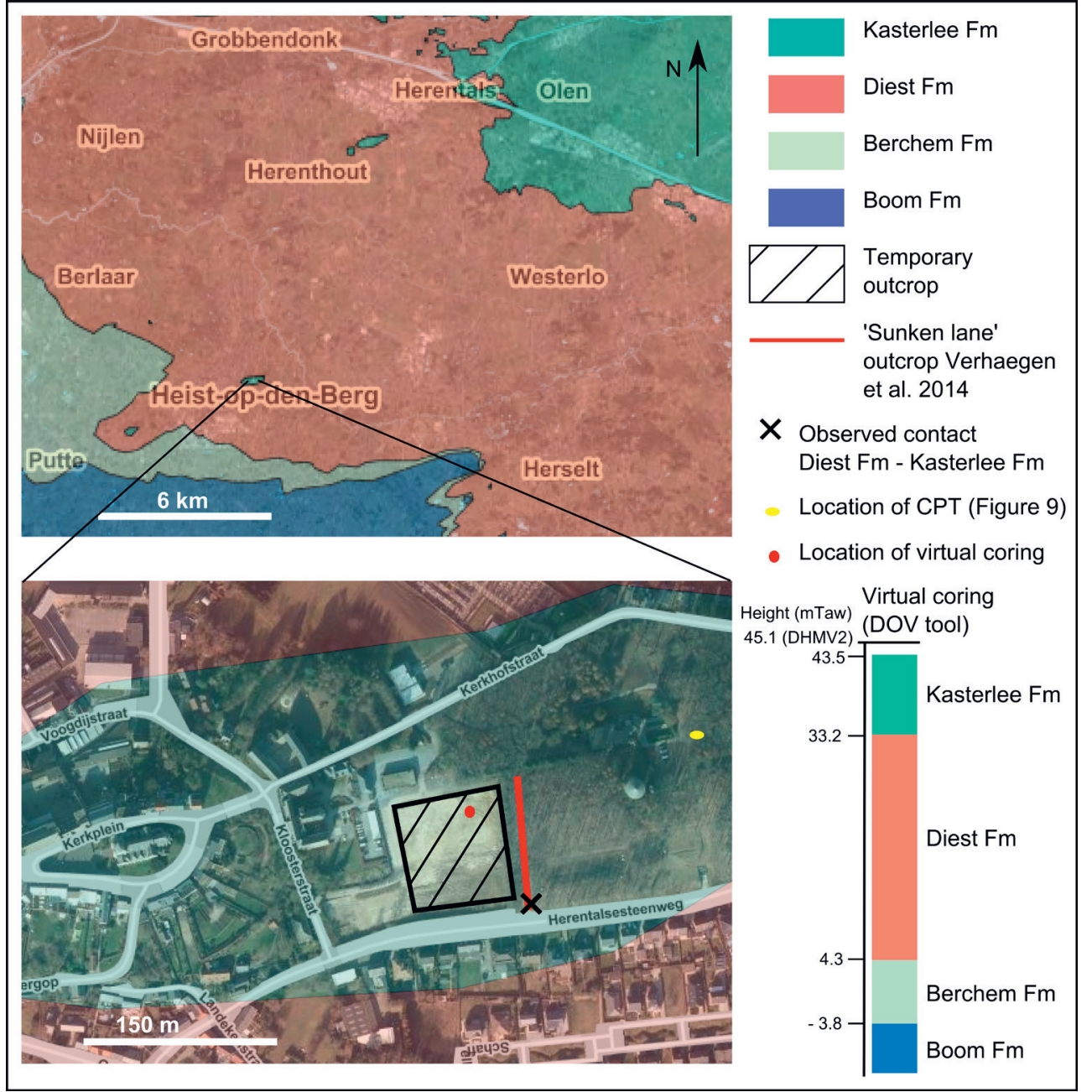

Figure 1. Geographical and geological situation of the temporary outcrop on top of the Heist-op-den-Berg hill, visualized with DOV (www.dov.vlaanderen. be) using the recent G3Dv3 geological model of the Flemish subsurface. DOV code of the sunken lane outcrop described in Verhaegen et al. (2014): TO20140919, DOV code of the temporary outcrop described in the current study: TO-20190617). $\mathrm{CPT}=$ cone penetration test. decreases to only a few percent. In the upper Heist-op-den-Berg unit, while the grainsize distribution is similar to the Beerzel unit, the glauconite content further decreases, multiple thin but continuous gray to purple clay laminae occur and some iron oxidation crusts are present. To the north, a similar subdivision can be interpreted in the section of the Olen outcrop (Louwye et al., 2007, fig. 3). Further basinward, however, no base gravel is found and the internal architecture of the unit changes. In the type area of the Kasterlee Formation, west of Kasterlee, the formation consists of a fine-grained green glauconitic sand, while more to the east, in the Mol-Dessel area, the formation can be subdivided into a lower clayey unit (clayey Kasterlee unit) and an upper sandy, less glauconitic unit (Kasterlee-sensu-Gulinck unit or lower Mol unit) which is now interpreted as a lower unit of the Mol Formation (Vandenberghe et al., 2020, this volume).

\section{Field observations and sampling}

In a large outcrop at the eastern end of the excavation for construction, just next to the sunken lane, the middle Beerzel unit and upper Heist-op-den-Berg unit of the Kasterlee Formation were found, as expected (Fig. 2a\&b). There is a slight apparent dip of the observed layers to the north, based on the contact between the Beerzel and Heist-op-den-Berg units (Fig. 2b). The Beerzel unit could also be observed in an excavated elevator shaft and in another deeper part of the outcrop, while the basal Hallaar unit could only be observed on the construction site in the deepest elevator shaft, in which it was not allowed to take samples (Fig. 2h). The Hallaar unit and Diest Formation could also be observed at the base of the sunken lane next to the temporary outcrop, described by Verhaegen et al. (2014), where samples could be taken.

The Diest Formation can be easily recognized based on its coarser grain size, high glauconite content and related green color, and lower clay content (Fig. 2i). Near the base, the Hallaar unit is a poorly sorted brown clayey sand with a significant amount of glauconite and the disperse occurrence of rounded and flattened flint pebbles (Fig. 2i). The boundary with the Diest Formation could only be observed in the very small outcrop in the sunken lane, where its characteristics cannot be well observed. There is a rather abrupt change from the green sand of the Diest Formation to the more brownish sand of the Hallaar unit. The top part of the Hallaar unit observed in the elevator shaft of the temporary outcrop consists of middle brownish to greenish sand with a high clay content and a significant amount of glauconite. It has a mottled appearance due to the occurrence of greener reduced clayey pockets within the brownish oxidized more sandy matrix (Fig. 2h). The transition to the Beerzel unit can be observed by the disappearance of this mottled character towards a more homogenous fine sand poor in clay (Fig. 2h).

The overlying Beerzel unit consists of a homogenous fine well-sorted white to yellow sand, without clay intercalations (Fig. 2f). Towards the base of the Beerzel unit irregular layers of brown sand occur although in general the sand was less subject to oxidation (Fig. 2g). Even though the boundary between the Beerzel unit and overlying Heist-op-den-Berg unit can be placed at the base of the first purple clay layer, the sand at the top of the Beerzel unit also includes some very thin clay laminae accentuated by later limonite precipitation (Fig. 2c).

About $1.2 \mathrm{~m}$ of Heist-op-den-Berg unit is preserved on top of the outcrop, beneath the soil. The Heist-op-den-Berg unit consists of an alternation of well-sorted fine brownish sand and gray to purple clay intercalations which vary in thickness from one to ten centimeter. The boundary between the Beerzel unit and Heist-op-den-Berg unit can be placed at the base of the first purple clay layer which is at least $10 \mathrm{~cm}$ thick (Fig. 2c). The next thick purple clay layer occurs $80 \mathrm{~cm}$ above the basal layer, with in between an intercalation of many thinner gray clay and sand layers (Fig. 2d). The top part of the Heist-op-den-Berg unit in the outcrop, beneath the soil, consists mainly of fine brown sand with fewer clay intercalations (Fig. 2e). At the top of the hill, the Heist-op-den-Berg unit is possibly up to $3.6 \mathrm{~m}$ thick, based on the interpretation of the CPT log in Figure 9. 


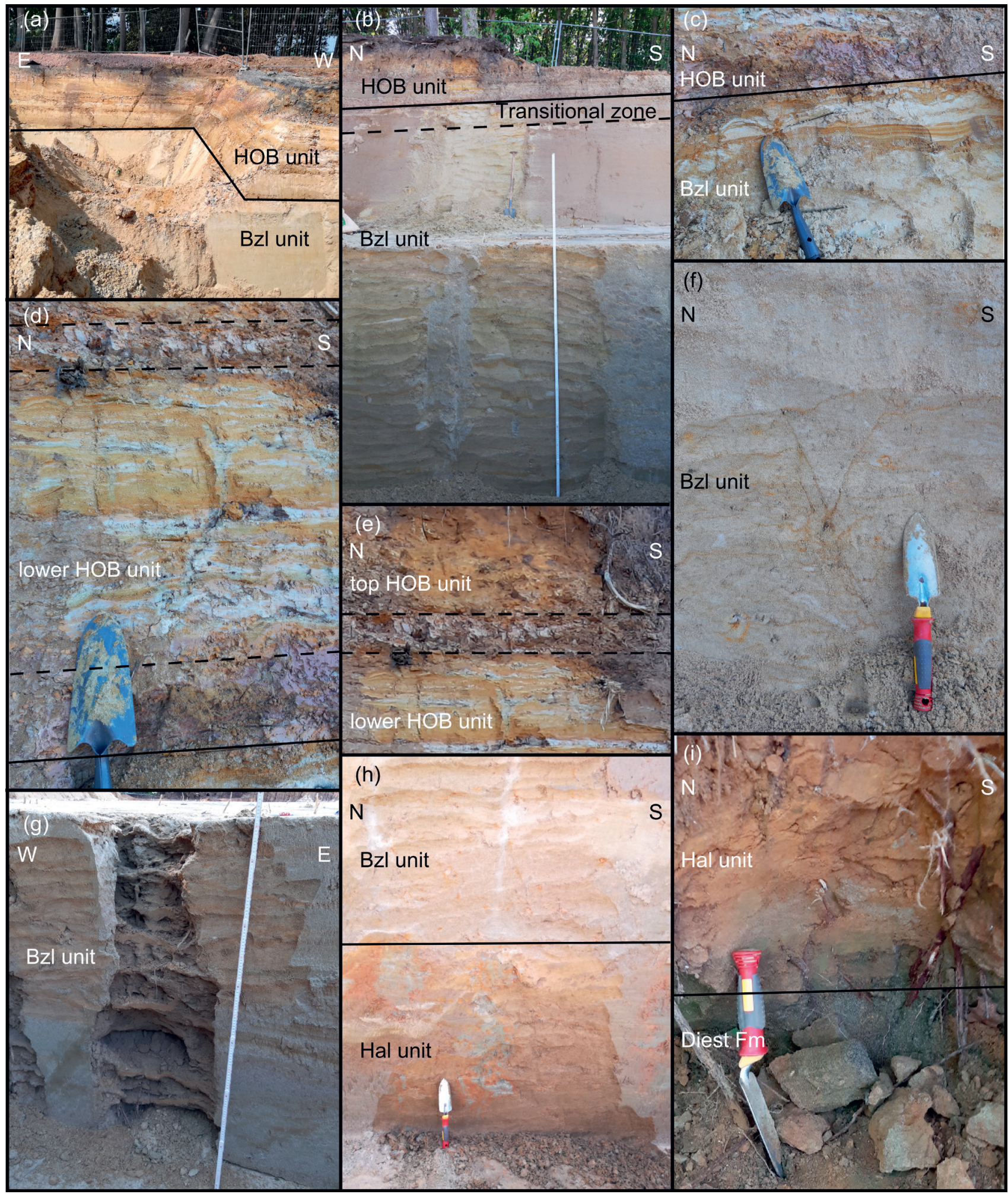

Figure 2. Pictures visualizing the characteristics of different units at the temporary outcrop, except for (i) which was taken at the base of the sunken lane next to the outcrop. (a) overview of contact between Bzl (Beerzel) and HOB (Heist-op-den-Berg) unit, (b) sampled section, (c) contact between Bzl and HOB unit, (d) detail of HOB unit sand-clay alternation, (e) top of HOB unit, (f) Bzl unit, (g) irregular brown oxidized layers more resistant to weathering near base of Bzl unit, (h) contact between Hal (Hallaar) and Bzl unit, (i) contact between Diest Formation and Hal unit. Color differences of the units between different pictures are (partly) due to different lighting conditions.

A small displacement of unknown origin which might be related to slope instability, resembling a fault-related flexure, could be observed in the outcrop, accentuated by the clay layers of the Heist-op-den-Berg unit (Fig. 3). As the outcrop is oriented NNW-SSE, the displacement shows a drop of approximately $20 \mathrm{~cm}$ of the southern block relative to the northern block.

The observations described are summarized in a composite litholog of the studied section on top of the Heist-op-den-Berg hill (Fig. 4).
In the construction site, samples were taken along a continuous vertical transect from the base of an elevator shaft containing Beerzel unit sand to the top of the outcrop wall (Fig. 5). Samples were taken every $30 \mathrm{~cm}$. In total, 15 samples of the Beerzel unit were taken, from the bottom of the pit to the contact with the Heist-op-den-Berg unit with the purple clay layer. For the Heistop-den-Berg unit, five samples were taken, of which two samples of sand layers, two samples of thick purple clay layers and one sample of a finer gray clay layer. For the Hallaar unit, three 


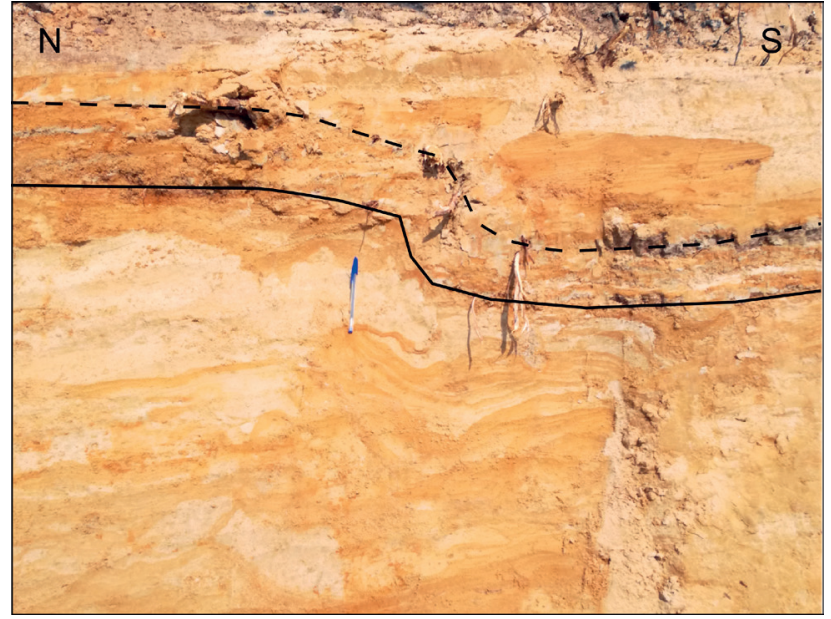

Figure 3. Apparent small displacement visualized by the contact between the Beerzel and Heist-op-den-Berg units.

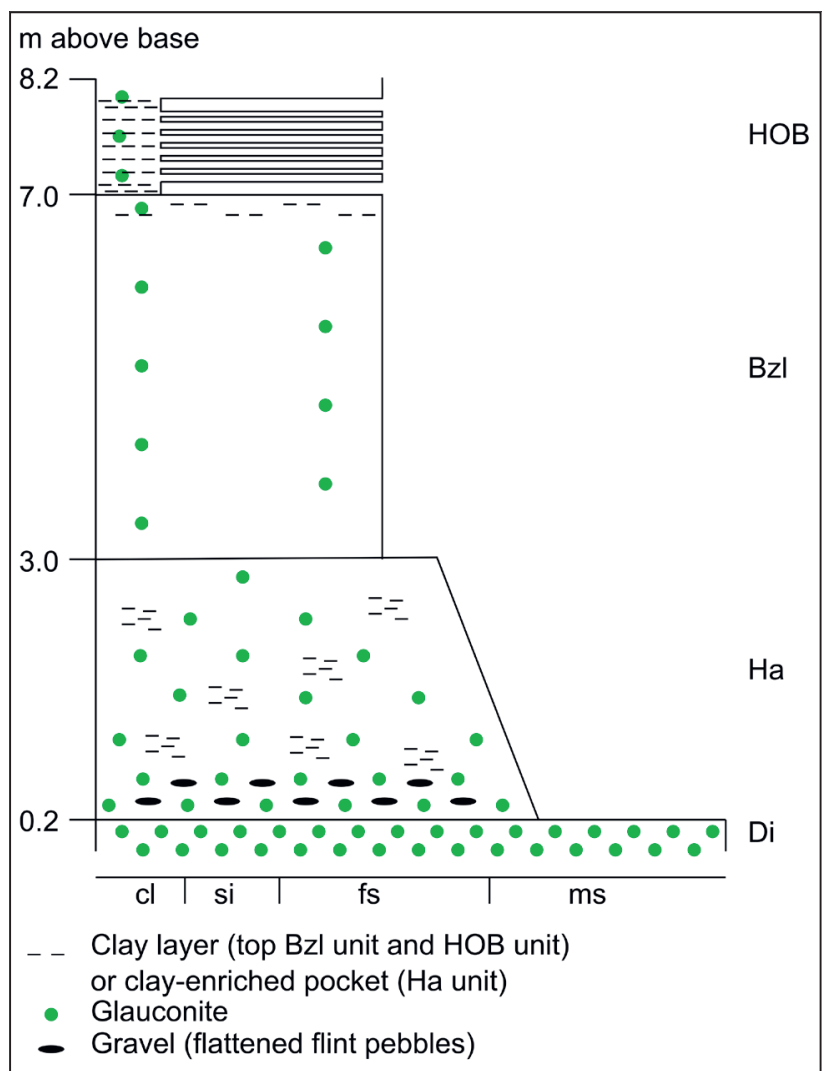

Figure 4. Litholog of the described section. $\mathrm{Di}=$ Diest Formation, $\mathrm{Ha}=$ Hallaar unit, $\mathrm{Bzl}=$ Beerzel unit, $\mathrm{HOB}=$ Heist-op-den-Berg unit. $\mathrm{cl}=$ clay, $\mathrm{si}=$ silt, $\mathrm{fs}=$ (very) fine sand, $\mathrm{ms}=$ medium sand.

samples were taken along the sunken lane; one at the contact with the Diest Formation containing a dispersed gravel, one in the same outcrop $30 \mathrm{~cm}$ higher, and one near the middle of the Hallaar unit. One sample was taken of the Diest Formation at the bottom of the sunken lane, just below the contact with the Hallaar unit.

\section{Analytical methods}

All samples were homogenized after drying in an oven at $60{ }^{\circ} \mathrm{C}$ and split into three subsamples. A first subsample was used for mineralogical analysis. The samples were mixed with $10 \mathrm{wt} . \%$ of an internal standard $(\mathrm{ZnO})$ and milled in a wet state for 5 minutes in a McCrone micronizing mill (Snellings et al., 2010). After drying, the powder was passed through a $150 \mu \mathrm{m}$ sieve and side loaded into the measurement holder. X-ray diffraction measurements were executed using a Philips PW1830 X-ray diffractometer in a Bragg-Brentano setup with $\mathrm{CuK} \alpha$ radiation, a graphite monochromator and a gas proportional detector. The operational parameters of the device were set at $45 \mathrm{kV}$ and $30 \mathrm{~mA}$ from 5 to $65^{\circ} 2 \theta$ and a $2 \mathrm{~s}$ scanning time per step. The quantitative mineralogical composition was determined by processing the measured XRD patterns using the Quanta software package (C) Chevron ETC).

The second subsample was used for grain size analysis. Possible cementing agents in the form of organic matter, carbonate or iron oxides were removed following the procedures described by Jackson (1975), though the initial content of organic matter and carbonate was negligible in the studied samples. Grain size distribution was determined through laser diffraction analysis using a Beckman Coulter LS 13320.

\section{Results of granulometry and mineralogy}

\subsection{Grain size distribution}

The grain size distributions (Fig. 6) of the samples display significant variations, which can be described in terms of their percentile data (Table 1). Starting from the bottom, the sample of the Diest Formation is a medium to coarse sand with a modal grain size of $429 \mu \mathrm{m}$. It is the coarsest sediment encountered in the section, with a D90 of $567 \mu \mathrm{m}$ and a D50 of $175 \mu \mathrm{m}$. Although most of the particles are situated in the medium to coarse sand population, a small population of 0.5 to $10 \mu \mathrm{m}$ sized particles is also present, evidenced by the low D10 value of $0.8 \mu \mathrm{m}$. According to grain size analyses by Verhaegen (2020, this volume), the modal grain size of the Diest Sand is $257 \pm 55 \mu \mathrm{m}$ and $316 \pm 55 \mu \mathrm{m}$ in the adjacent areas of the Antwerp Campine and Hageland respectively. These average values are lower than the measured value of modal grain size at Heist-op-den-Berg, yet still significantly higher than the modal grain size measured for the Kasterlee Formation units. The increased modal grain size of the top of the Diest Formation at Heist-op-den-Berg is also confirmed by Verhaegen et al. (2014) who measured a modal grain size of $375 \mu \mathrm{m}$.

The three samples of the Hallaar unit are characterized by a distinctly bimodal distribution in the fine to medium sand range, with a D50 in the range of 73 to $84 \mu \mathrm{m}$ and population modes around 140 and $430 \mu \mathrm{m}$. In sample Ha1, which is situated close to the transition into the Diest Formation, the coarsest population is dominant. The D90 values also show a decrease from Ha1 to $\mathrm{Ha} 3$, indicating an evolution towards finer sediments in the Beerzel unit.

The Beerzel unit samples typically are fine sands which show little vertical variation: all distributions have D50 values in-between 163 and $188 \mu \mathrm{m}$ and D90 values in-between 255 and $278 \mu \mathrm{m}$, with a mode between 185 and $204 \mu \mathrm{m}$.

The samples of the Heist-op-den-Berg unit can be divided into two lithologies: $\mathrm{H} 4, \mathrm{H} 2$ and $\mathrm{H} 1$ were sampled in clayey horizons, while $\mathrm{H} 5$ and $\mathrm{H} 3$ were sampled in sandy horizons. The latter two samples show a distribution which closely resembles the Beerzel unit samples, with a D50 of 149 and $159 \mu \mathrm{m}$, a D90 of 241 and $257 \mu \mathrm{m}$, and a mode of $185 \mu \mathrm{m}$. The clayey samples are represented by multimodal distributions with a low D50 of 6 to $13 \mu \mathrm{m}$, typical of very fine silt with a high clay content.

\subsection{Mineralogy}

The sand-sized samples are mainly composed of quartz, though in the samples of the Diest Formation and Hallaar unit, glauconite (2:1 Fe clay) is also an important component (Fig. 7). Glauconite is most prominent in the sample of the Diest Formation, in which it takes up $56 \mathrm{wt} . \%$ of the mass. The weight percentage of glauconite decreases from 34 to 13 wt.\% in the samples of the Hallaar unit. In the Beerzel and Heist-op-den-Berg samples, the amount of glauconite is more or less constant, ranging from 2 to $6 \mathrm{wt} . \%$. The decrease in glauconite is expressed well by a glauconite/quartz ratio, which drops from $>1.5$ in the Diest Formation to $<0.1$ in the Kasterlee Formation, with a transitional zone in the Hallaar unit. Only in the clay layers of the Heist-op-den-Berg unit there is again a slight increase of glauconite/quartz (Fig. 8).

Associated with quartz is feldspar (both plagioclase and $\mathrm{K}$-feldspar), which ranges from 0 to $6 \mathrm{wt} . \%$. The highest proportions of feldspar are present in the Beerzel unit and sandy 


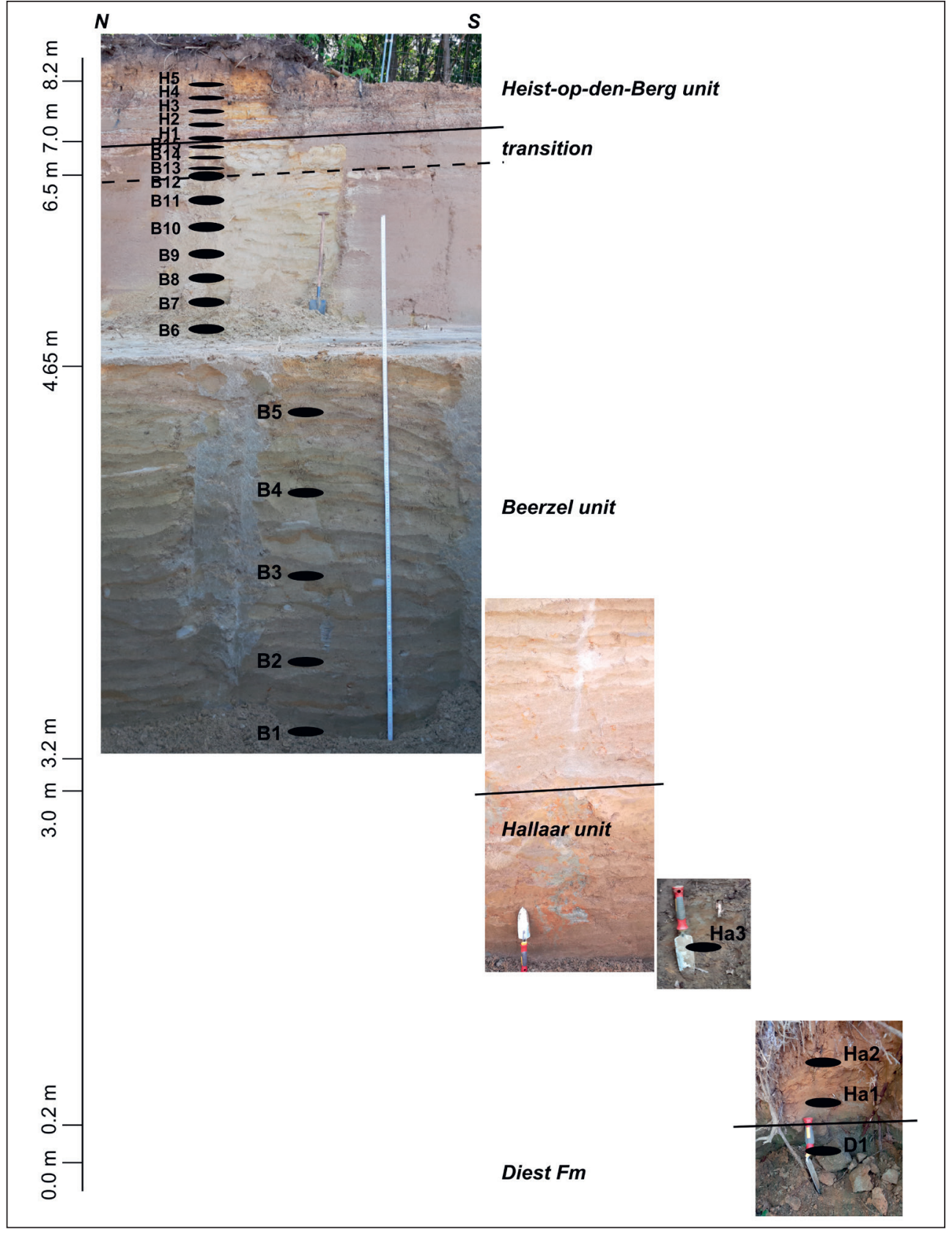

Figure 5. Overview of samples taken at the temporary outcrop (for the Beerzel and Heist-op-denBerg units) and at the base of the sunken lane (for the Hallaar unit and Diest Formation). Sample H2 was split into a subsample of a clay layer and a sand layer. Color differences in the Beerzel unit between the different pictures are due to different lighting conditions. The Diest-Kasterlee Formation boundary is situated at $35 \mathrm{~m}$ TAW.

samples of the Heist-op-den-Berg unit (4-6 wt.\%) (Fig. 7). The Kasterlee Formation in general has a significantly higher content of feldspar compared to the Diest Formation sample, visualized by a feldspar/quartz ratio (Fig. 8).

In samples with an important fine grain size fraction, such as the Diest Formation, Hallaar unit and clay layers of the Heistop-den-Berg unit, 2:1 Al-clay minerals make up a larger part of the bulk mineralogical composition (Figs 7, 8). The 2:1 Alclay minerals range from 3 to $15 \mathrm{wt} . \%$ in the sand samples, and, based on analyses by Adriaens (2015), they mainly consist of muscovite, complemented by smectite, illite and interstratified illite-smectite in the finest fractions. In the three clay-enriched samples of the Heist-op-den-Berg unit, the proportions of clay minerals are logically significantly higher, representing up to 75 wt. $\%$ of the bulk mass with a significantly higher 2:1 Al-clay / quartz ratio (Figs 7,8 ).

Kaolinite is also present, be it in minor amounts ( 0 to $7 \mathrm{wt} . \%$ in sand samples). Kaolinite is only an important component in the sandy (5-7 wt.\%) and clayey (20-25 wt.\%) samples of the Heist-op-den-Berg unit (Fig. 7). A ratio of kaolinite versus 2:1 Al-clay minerals also indicates that the importance of kaolinite in the clay mineral fraction strongly increases in the Heist-op-denBerg unit (Fig. 8).

Goethite is present in minor amounts (0 to 4 wt.\%, Fig. 7) and is usually interpreted as a weathering product of glauconite in glauconite-bearing sands. A ratio of goethite to glauconite indicates that goethite is mainly important in the Heist-op-denBerg unit, yet also occurs in minor amounts in the Hallaar unit and the top of the Beerzel unit (Fig. 8).

\section{Discussion}

The Kasterlee Formation at the studied outcrop can be clearly distinguished from the Diest Formation by its much lower glauconite content, finer grain size and generally higher feldspar content. The subdivision of the Kasterlee Formation into three distinct units in its southern outcrop area, as proposed by Fobe (1995) and Verhaegen et al. (2014), is further confirmed in the studied outcrop and the characteristics of the different units can now be clearly defined, making them easily recognizable in outcrops or boreholes (Table 2).

Hallaar unit: The basal Hallaar unit has transitional characteristics between the Diest Formation and Kasterlee Formation. At its base in the outcrop area a disperse gravel of flattened and partly weathered flint pebbles is present, together with coarse quartz grains and white weathered silex, described in detail in Verhaegen et al. (2014). Glauconite content is significantly lower than in the Diest Formation but concentrations of $>10 \%$ and a glauconite/quartz ratio of $0.20-0.68$ are still present. The grain size distribution is bimodal. The coarser 


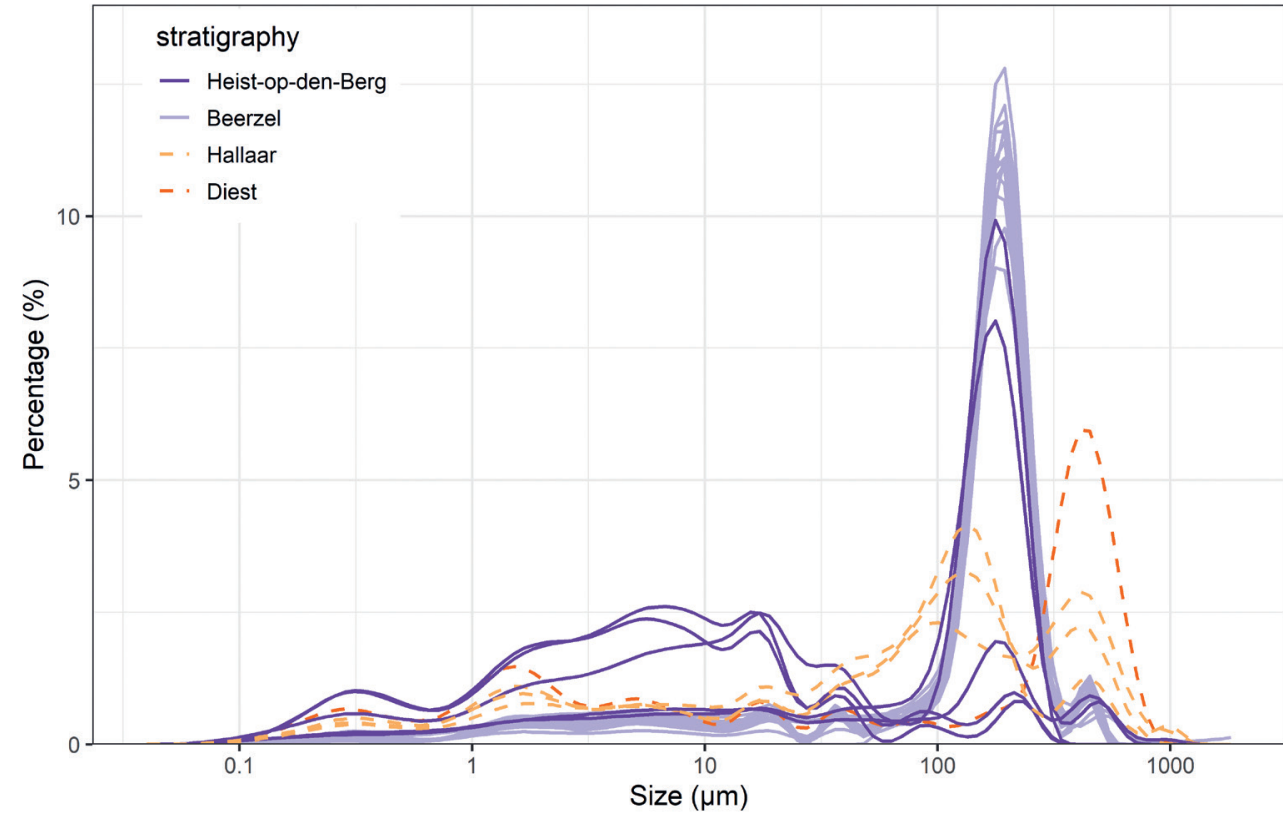

Figure 6. Grain size distributions of the samples collected for this study, colored according to their stratigraphical origin. For the Heist-op-den-Berg unit, three clayey and two sandy samples were measured.

\begin{tabular}{lrrrrrr}
\hline Sample & Mode & Skewness & Kurtosis & D10 & D50 & D90 \\
\hline H5 & 185.4 & -1.5 & 1.4 & 2.9 & 149.0 & 257.1 \\
H4 & 7.1 & 0.1 & 0.0 & 0.5 & 5.6 & 34.1 \\
H3 & 185.4 & -1.6 & 1.4 & 3.1 & 158.5 & 241.3 \\
H2 & 18.0 & -0.1 & -0.5 & 0.8 & 13.1 & 211.0 \\
H1 & 5.9 & 0.1 & -0.3 & 0.5 & 5.5 & 63.1 \\
B15 & 185.4 & -1.8 & 2.4 & 4.5 & 172.6 & 256.1 \\
B14 & 203.5 & -3.0 & 8.8 & 4.3 & 188.0 & 269.2 \\
B13 & 203.5 & -1.8 & 2.5 & 5.2 & 178.2 & 269.4 \\
B12 & 203.5 & -1.9 & 2.4 & 4.3 & 184.9 & 273.6 \\
B11 & 203.5 & -2.1 & 3.8 & 7.4 & 182.3 & 263.0 \\
B10 & 203.5 & -2.2 & 4.5 & 9.8 & 177.3 & 254.9 \\
B9 & 203.5 & -2.0 & 3.4 & 7.1 & 173.3 & 255.3 \\
B8 & 203.5 & -2.1 & 3.4 & 6.3 & 178.7 & 263.7 \\
B7 & 185.4 & -2.2 & 4.1 & 7.7 & 176.9 & 256.0 \\
B6 & 203.5 & -1.9 & 2.9 & 5.3 & 183.9 & 277.5 \\
B5 & 203.5 & -1.7 & 2.3 & 4.4 & 177.1 & 278.3 \\
B4 & 203.5 & -2.1 & 3.7 & 5.9 & 177.6 & 266.3 \\
B3 & 185.4 & -1.5 & 1.3 & 3.1 & 163.4 & 263.0 \\
B2 & 185.4 & -1.8 & 2.0 & 4.3 & 171.1 & 256.7 \\
B1 & 185.4 & -1.7 & 2.0 & 4.4 & 171.7 & 264.9 \\
Ha3 & 140.1 & -0.9 & 0.0 & 1.6 & 72.8 & 275.8 \\
Ha2 & 140.1 & -0.8 & -0.4 & 1.3 & 85.4 & 411.3 \\
Ha1 & 429.2 & -0.7 & -0.7 & 1.2 & 83.6 & 483.0 \\
D1 & 429.2 & -0.5 & -1.3 & 0.8 & 174.9 & 567.0 \\
\hline & & & & & & \\
\hline
\end{tabular}

Table 1. Summary statistics of the grain size distributions shown in Figure 6. The mode, D10, D50 and D90 are expressed in $\mu \mathrm{m}$, while the skewness and kurtosis are dimensionless numbers.

mode at $\sim 430 \mu \mathrm{m}$ is equal to the modal grain size of the Diest Formation and can be attributed to reworking of sediment from the Diest Formation. Another finer modal grain size is also present, at $\sim 140 \mu \mathrm{m}$, which is more typical of the Kasterlee Formation and represents the new sediment input. The sediment has a large fine fraction, with $50 \%$ of grains $<85 \mu \mathrm{m}$. The Hallaar unit has a similar 2:1 Al-clay content (11-15\%, 2:1 Al-clay/quartz ratio of $0.22-0.23$ ) to the Diest Formation, yet higher than the Beerzel unit and the sandy parts of the Heist-op-den-Berg unit. Feldspar content (4-5\%, feldspar/quartz ratio of 0.06-0.09) is significantly higher compared to the Diest Formation and similar to the overlying Beerzel and
Heist-op-den-Berg units. The Hallaar unit also contains a certain amount of goethite (0-2\%, goethite/glauconite ratio of $0.003-0.095)$, which may be linked to a phase of oxidation prior to and during deposition of this unit. In outcrops or cores, the Hallaar unit may be recognized by its brownish-green weathered color if oxidized above the groundwater table, significant glauconite and clay content, and the mottled appearance due to the presence of greengrayish clay-enriched patches of sediment.

Beerzel unit: The Beerzel unit can be clearly distinguished from the Hallaar unit by the shift in color from brown-green to yellow-white. Glauconite content is significantly lower in the 

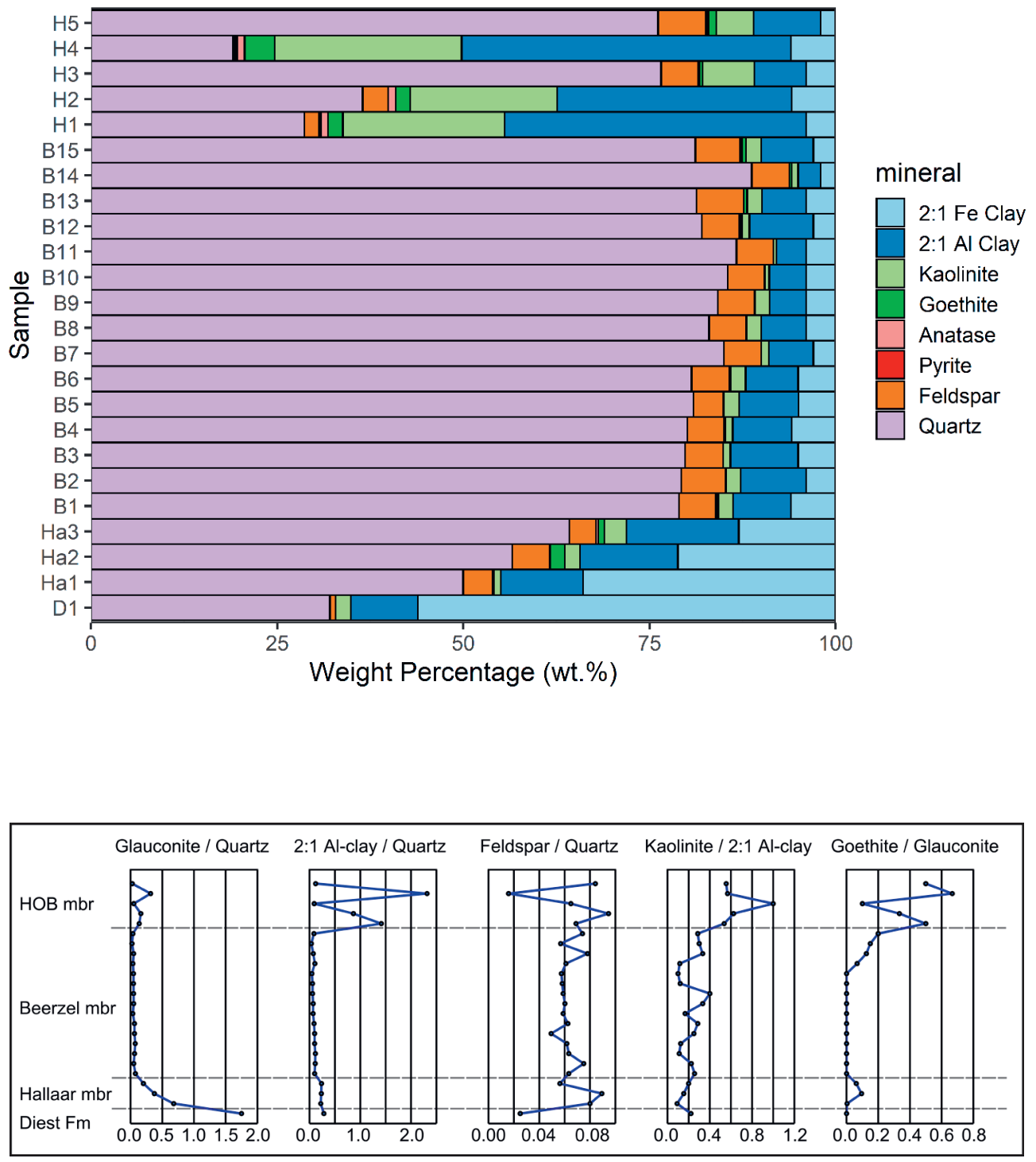

Figure 8. Ratios of key mineral components in the studied samples. Glauconite content is based on 2:1 Fe clay (Fig. 7).

\begin{tabular}{|c|c|c|c|c|}
\hline & Diest Fm* & Hallaar unit & Beerzel unit & Heist-o/d-Berg unit \\
\hline Color & green & brown-green & yellow-white & $\begin{array}{l}\text { brown sand, gray and } \\
\text { purple clay }\end{array}$ \\
\hline Sedimentology & homogeneous & $\begin{array}{l}\text { mottled, } \\
\text { disperse base } \\
\text { gravel }\end{array}$ & $\begin{array}{l}\text { homogeneous } \\
\text { and (gray/ } \\
\text { purple) clay }\end{array}$ & intercalations of sand \\
\hline mode $(\mu m)$ & $\sim 430$ & $\begin{array}{l}\sim 140 \text { and } \\
\sim 430\end{array}$ & $\sim 195$ & $\sim 185$ \\
\hline sorting & - & - & + & + \\
\hline $\begin{array}{l}\text { fine fraction } \\
(<10 \mu \mathrm{m})\end{array}$ & + & + & - & $\begin{array}{l}\text { - (sand layers }) / \\
++ \text { (clay layers) }\end{array}$ \\
\hline Glauconite (\%) & $>40$ & $10-35$ & $2-6$ & $2-4 / 4-6$ \\
\hline Glauconite/quartz & 1.75 & $0.20-0.68$ & $0.02-0.08$ & $0.03-0.05 / 0.14-0.32$ \\
\hline Feldspar (\%) & 1 & $4-5$ & $4-6$ & $5-6 / 0-3$ \\
\hline Feldspar/quartz & 0.03 & $0.06-0.09$ & $0.05-0.08$ & $0.07-0.08 / 0.02-0.10$ \\
\hline 2:1 Al-clay (\%) & 9 & $11-15$ & $3-9$ & $7-9 / 32-44$ \\
\hline 2:1 Al-clay/quartz & 0.28 & $0.22-0.23$ & $0.03-0.11$ & $0.09-0.12 / 0.9-2.3$ \\
\hline Kaolinite (\%) & 2 & $1-3$ & $0-2$ & $5-7 / 20-25$ \\
\hline Kaolinite/2:1 Al-clay & 0.2 & $0.1-0.2$ & $0.1-0.4$ & $0.5-0.6 / 0.6-1.0$ \\
\hline Goethite (\%) & 0 & $0-2$ & $0-1$ & $0-1 / 2-4$ \\
\hline Goethite/glauconite & 0 & $0.003-0.095$ & $0-0.2$ & $0.1-0.5 / 0.3-0.7$ \\
\hline
\end{tabular}

Table 2. Reference parameters for the different units, based on the analyses done in this paper. The values for the Diest Formation $(*)$ are based on the single sample analyzed for this paper, just below the boundary with the Kasterlee Formation. For the Heist-op-den-Berg unit, mode is given for the sand layers and mineralogical values are given for both the sand and clay layers. 
Beerzel unit (2-6\%, glauconite/quartz ratio of $0.02-0.08)$. The grain size distribution curves show a very well sorted sediment with a modal grain size between 185 and $204 \mu \mathrm{m}$ and only a small amount of material outside of the 100 to $300 \mu \mathrm{m}$ range. The 2:1 Al-clay content of the Beerzel unit (3-9\%, 2:1 Al-clay/quartz ratio of $0.03-0.11$ ) is lower than in the Hallaar unit and similar to the sandy layers of the Heist-op-den-Berg unit, and there is an overall decrease to the top. Feldspar content remains largely constant in the Beerzel unit (4-6\%, feldspar/quartz ratio of $0.05-$ $0.08)$. In outcrops or cores, the Beerzel unit can be recognized by its yellow to white color, low glauconite and clay content. It also has a generally homogeneous appearance, except for possible irregular brownish intercalations due to oxidation above the groundwater table, linked to groundwater fluctuations.

Heist-op-den-Berg unit: The base of this unit can be placed at the base of the first thick purple clay layer $(>10 \mathrm{~cm})$. The glauconite content of the sandy layers in the Heist-op-den-Berg unit is similar to the Beerzel unit (2-4\%, glauconite/quartz ratio of $0.03-0.05$ ). The grain size distribution of the sandy layers is very similar to the Beerzel unit, well sorted with a mode at $\sim 185 \mu \mathrm{m}$, though with a slightly larger fine fraction. Both feldspar content (5-6\%, feldspar/quartz ratio of $0.07-0.08)$ and 2:1 Alclay content $(7-9 \%, 2: 1$ Al-clay/quartz ratio of $0.09-0.12)$ are similar to the Beerzel unit. In contrast to the Beerzel unit, it has more kaolinite $(5-7 \%$, kaolinite/2:1 Al-clay ratio of $0.6-1.0)$ indicating an increased component of continental sediment supply. The clay layers are mainly composed of 2:1 Al-clays (32$44 \%, 2: 1$ Al-clay/quartz ratio of $0.9-2.3)$ and kaolinite (20-25\%, kaolinite/2:1 Al-clay ratio of 0.5-0.6), and a considerable amount of goethite is present as well $(2-4 \%$, goethite/glauconite ratio of $0.3-0.7)$. In outcrops and cores, the Heist-op-den-Berg unit can be easily recognized by the brown, due to oxidation, well-sorted fine-grained sand with a very low glauconite content and the occurrence of thin gray and thick purple clay intercalations.

The identified lithological units can be recognized without difficulties in CPT logs of the subsurface (Fig. 9), indicating that the units can be followed to other locations in the southern outcrop and subcrop area of the Kasterlee Formation. The different CPT parameters (measured cone resistance and local friction; calculated parameters e.g. friction ratio, soil behavior indexes and conductivity) are proxies of lithology (e.g. grain size, clay content, etc.) and mechanical properties of every lithological unit (Schiltz, 2020, this volume). These characteristics can also be traced on the CPT logs further northeast into the basin, towards the Mol-Dessel area, where the Kasterlee Formation is defined as a clayey unit in between the Diest Formation and the Mol Formation (Fig. 10) (Vandenberghe et al., 2020, this volume). A clear threefold subdivision cannot be made in that area as a sandy middle unit, the Beerzel unit, is not present towards the northeast.

In Fobe (1995) and Verhaegen et al. (2014) the depositional environment of the Kasterlee Formation at Heist-op-den-Berg and Beerzel is interpreted as a semi-enclosed embayment. Reworking of Diest Sand into the Hallaar unit may have taken place during the transgression at the base of the Hallaar unit, forming a waveravinement surface which is typically characterized by erosion and reworking of the underlying sediments and the deposition of a basal grave (Catuneanu, 2006; Zecchin et al., 2019). After this period of reworking the clean homogenous Beerzel unit was deposited, followed by the Heist-op-den-Berg unit when the embayment was largely cut off from the marine environment. The significant amount of goethite in the Hallaar unit may be the result of the described reworking of partly weathered sediment of the Diest Formation, yet it may also be a recent phenomenon due to the position of the studied Hallaar unit samples close to the surface in the sunken lane. The Beerzel unit and Heist-op-denBerg unit are interpreted as the lower shoreface part of a barrier coast and the related shallow lagoon respectively (Reading, 1996). The fine well-sorted sand of the Beerzel unit was deposited in this very shallow wave-dominated marine setting, largely free of glauconite and homogenized due to bioturbation, as a prograding coastal barrier which straightened the irregular coastline of the Kasterlee Formation embayment. The irregular intercalations of brown oxidized sand in the Beerzel unit are likely not related to the sedimentation process but are rather post-depositional as a result of oxidation related to groundwater movements. Due to the presence of a coastal barrier, the lagoon which occurred between

\section{Heist-op-den-Berg}

Grain size

$$
\text { CPT logs }
$$

Field observations

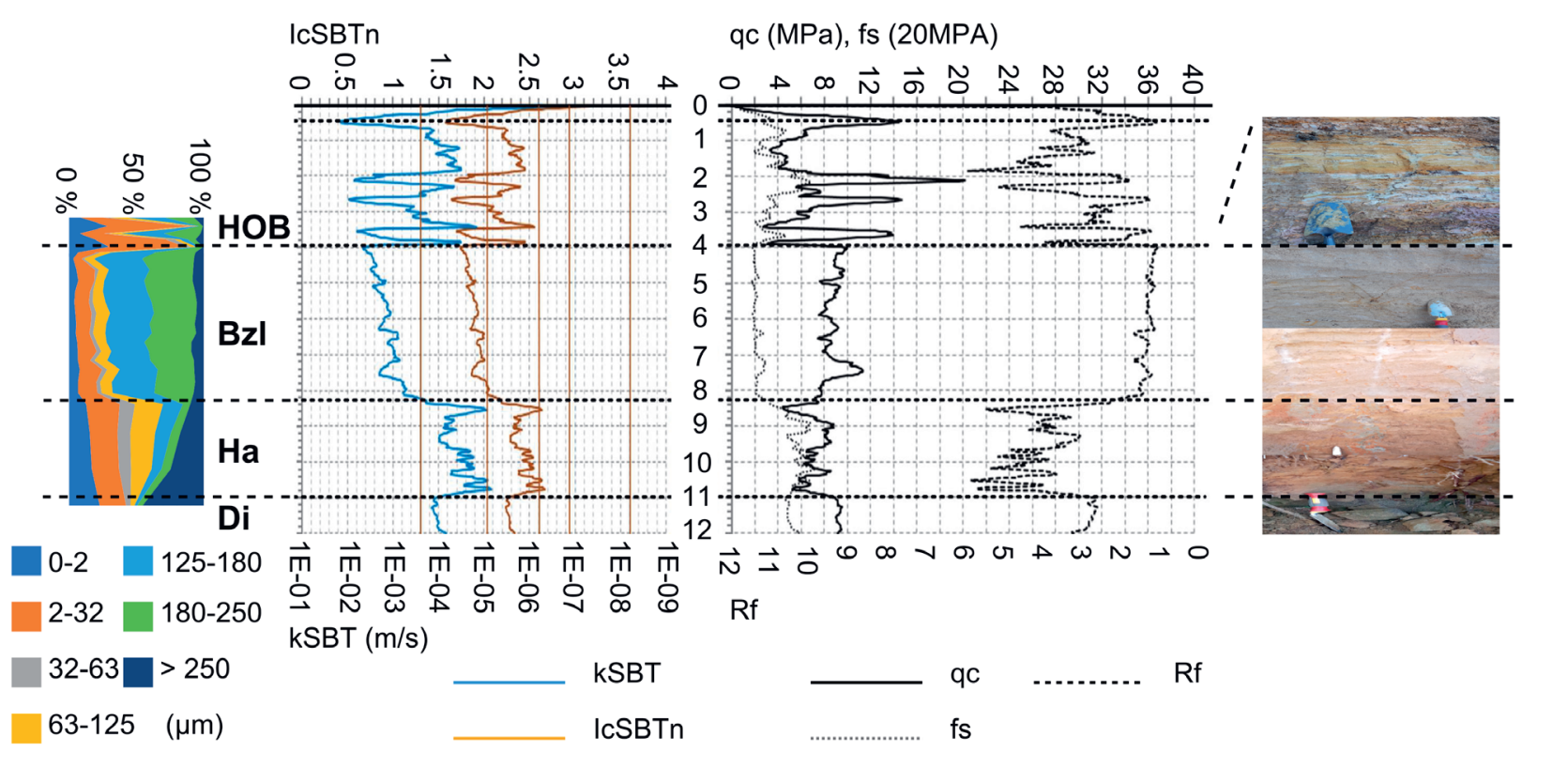

Figure 9. CPT (cone penetration test) logs taken at the top of Heist-op-den-Berg, near to the studied outcrop. A strong correlation can be made between the mechanical values captured on the CPT logs, the measured grain size distribution of the sediments and the field observations. Di $=$ Diest Formation, $\mathrm{Ha}=$ Hallaar unit, $\mathrm{Bzl}=$ Beerzel unit, $\mathrm{HOB}=$ Heist-op-den-Berg unit. Apparent strong color differences in the Beerzel unit are due to different lighting conditions between different pictures. $\mathrm{qc}=$ cone resistance, $\mathrm{Rf}=$ friction ratio, $\mathrm{fs}=$ local friction, $\mathrm{kSBT}=$ estimated hydraulic conductivity based on soil behavior type, $\mathrm{IcSBTn}=$ normalized soil behavior type index. 


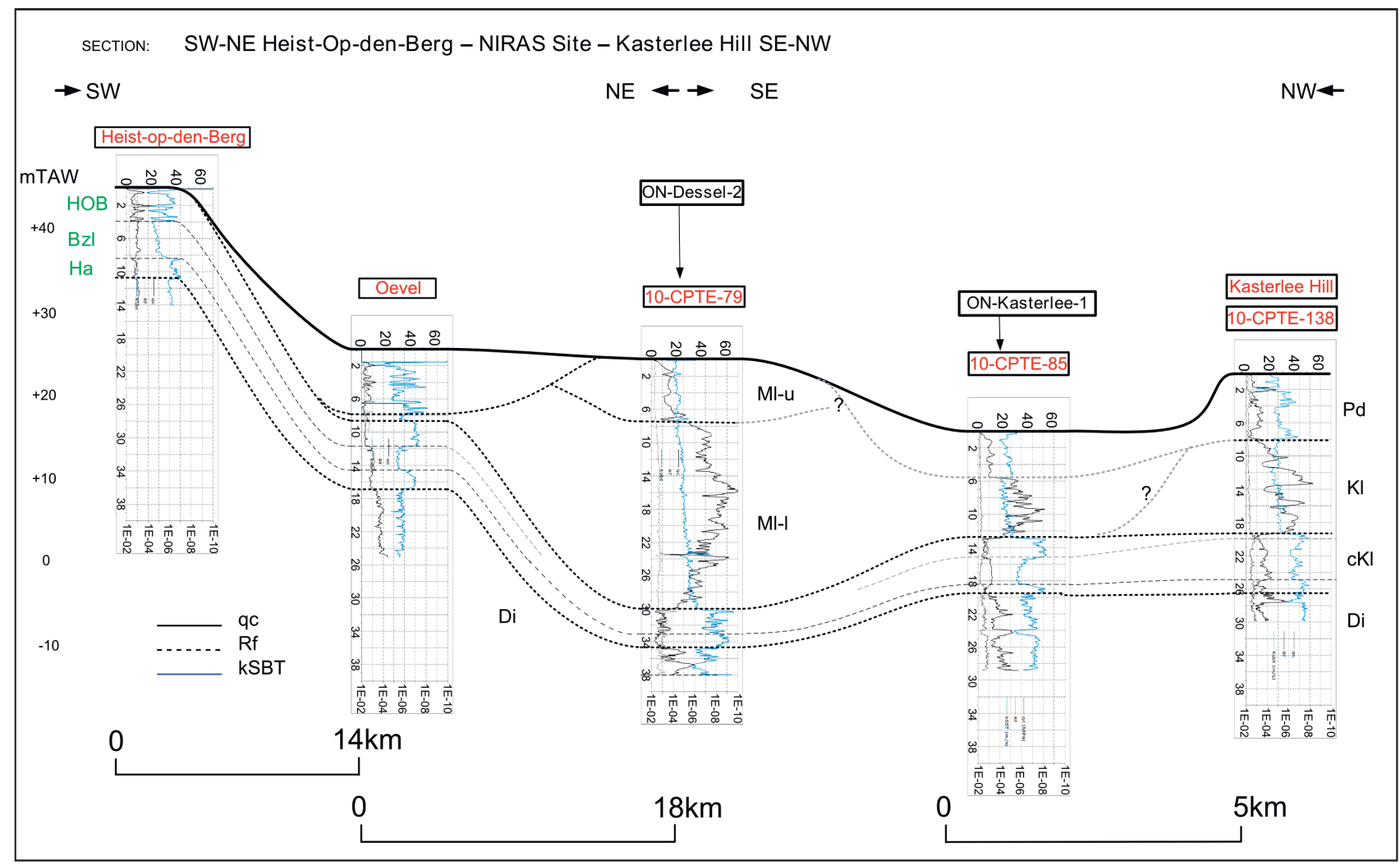

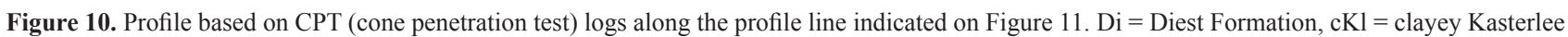
unit, Kl = typical Kasterlee Formation, Ml-1 = lower Mol unit or Kasterlee-sensu-Gulinck, Ml-u = upper coarse Mol Formation, Pd = Poederlee Formation, $\mathrm{Ha}=$ Hallaar unit, $\mathrm{Bzl}=$ Beerzel unit, $\mathrm{HOB}=$ Heist-op-den-Berg unit. Correlations of units above cKl based on Vandenberghe et al. (2020, this volume) and Schiltz (2020, this volume). $\mathrm{qc}=$ cone resistance, $\mathrm{Rf}=$ friction ratio, $\mathrm{kSBT}=$ estimated hydraulic conductivity.

the barriers and the coastal plain was largely cut off from the open sea which lead to a very quiet shallow peri-marine environment in which clay layers were deposited. The deposition of clay was regularly interrupted by the breaching of these barriers and/or by overwash events, leading to the very sharp autocyclic claysand intercalations observed in the Heist-op-den-Berg unit. The observed sediment was likely deposited close to the coastal barrier as the sand layers are very similar to the Beerzel unit sand. As there are no indications of tidal influences, it was likely a nontidal lagoon. The back-barrier position of the Heist-op-den-Berg unit and its clay layers is also compatible with the large amount of kaolinite in this unit, caused by weathered continental input, also proposed by Adriaens (2015). A lagoonal facies at the top of the Heist-op-den-Berg hill was already recognized by Van den Broeck (1882) and de Heinzelin (1963). The purple color of the thicker clay layers may be caused by the oxidation of organic matter and iron associated with this organic matter. The increased occurrence of goethite in the Heist-op-den-Berg unit, giving this unit its brownish color, is likely due to post-depositional oxidation as the Heist-op-den-Berg unit is now located in the aerated zone above the groundwater table. The position of the Heist-op-denBerg unit on top of the Beerzel unit in the current stratigraphic succession is a record of an overall progradation (i.e. regression) of the coastal succession during the deposition of the Kasterlee Formation (Fig. 11).

Halet (1935) recognized a similar threefold subdivision of the Kasterlee Formation ('Casterlien') between Herentals and Geel with a lagoonal facies consisting of clay-sand alternations at the top. More to the northeast, towards the area of Retie-Mol-Dessel, the thickness of the Kasterlee Formation decreases from $\sim 10 \mathrm{~m}$ to $\sim 5 \mathrm{~m}$ and the subdivision in three distinct units can no longer be observed (Vandenberghe et al., 2020, this volume) (Fig. 10). In this northeastern area, the Kasterlee Formation has a basal section including reworked elements, resembling the Hallaar unit, followed by a clayey unit with several clay intercalations, referred to as the clayey Kasterlee unit (Vandenberghe et al., 2020, this volume). A homogenized yellow-white sand unit correlated to the Beerzel unit does not occur in this area. Likely, at the time of deposition in this area, a coastal barrier had developed seawards so that only lagoonal deposits developed and the related sediment can be characterized as Heist-op-den-Berg unit, with the coeval deposition of coastal barrier sand (Beerzel unit) more to the northwest (Fig. 11). The overall NE-SW orientation and elongated shape of the lagoon in this area can also be observed based on hydrogeological models of variations in hydraulic conductivity (Rogiers et al., 2012). To the west of this area, in Kasterlee (Lichtaart ridge), the type section of the Kasterlee Formation occurs where a more homogeneous finegrained slightly glauconitic sandy unit is present, referred to as the typical Kasterlee Formation (Vandenberghe et al., 2020, this volume). Based on the description by Gullentops (1963) and Gullentops \& Huyghebaert (1999) at the Lichtaart ridge the typical Kasterlee Sand has similar characteristics to the Beerzel unit and these authors also interpret the typical Kasterlee Sand as a coastal barrier system. Based on CPT logs, below this unit a clayey unit with a threefold subdivision resembling the units described in Heist-op-den-Berg occurs, at least visible in the $\mathrm{ON}-$ Kasterlee-1 borehole (Schiltz, 2020, this volume; Vandenberghe et al., 2020, this volume) (Fig. 10). The coastal barrier sand, i.e. the Beerzel unit, deposited coeval to the clayey Kasterlee unit in the Retie-Dessel-Mol area to the east was likely deposited in the area of Kasterlee and coincides with the middle part of the clayey Kasterlee unit in the Kasterlee area.

To the north and west of the described coastal barrier and lagoon domain of the (clayey) Kasterlee Formation, coeval sediments appear to be absent and the Kasterlee Formation is geometrically replaced by the younger early Pliocene Kattendijk Sand (Gulinck, 1963). It is suggested that in that area a possibly present thin Kasterlee Formation was eroded at the turn of the Miocene to Pliocene. The typical Kasterlee sand in the type section of Kasterlee, on top of the threefold clayey unit (Fig. 10), does not fit well into this sedimentary system and could then be interpreted as a new sequence or a new phase in the filling of the basin. More in the direction of the continent this typical Kasterlee 


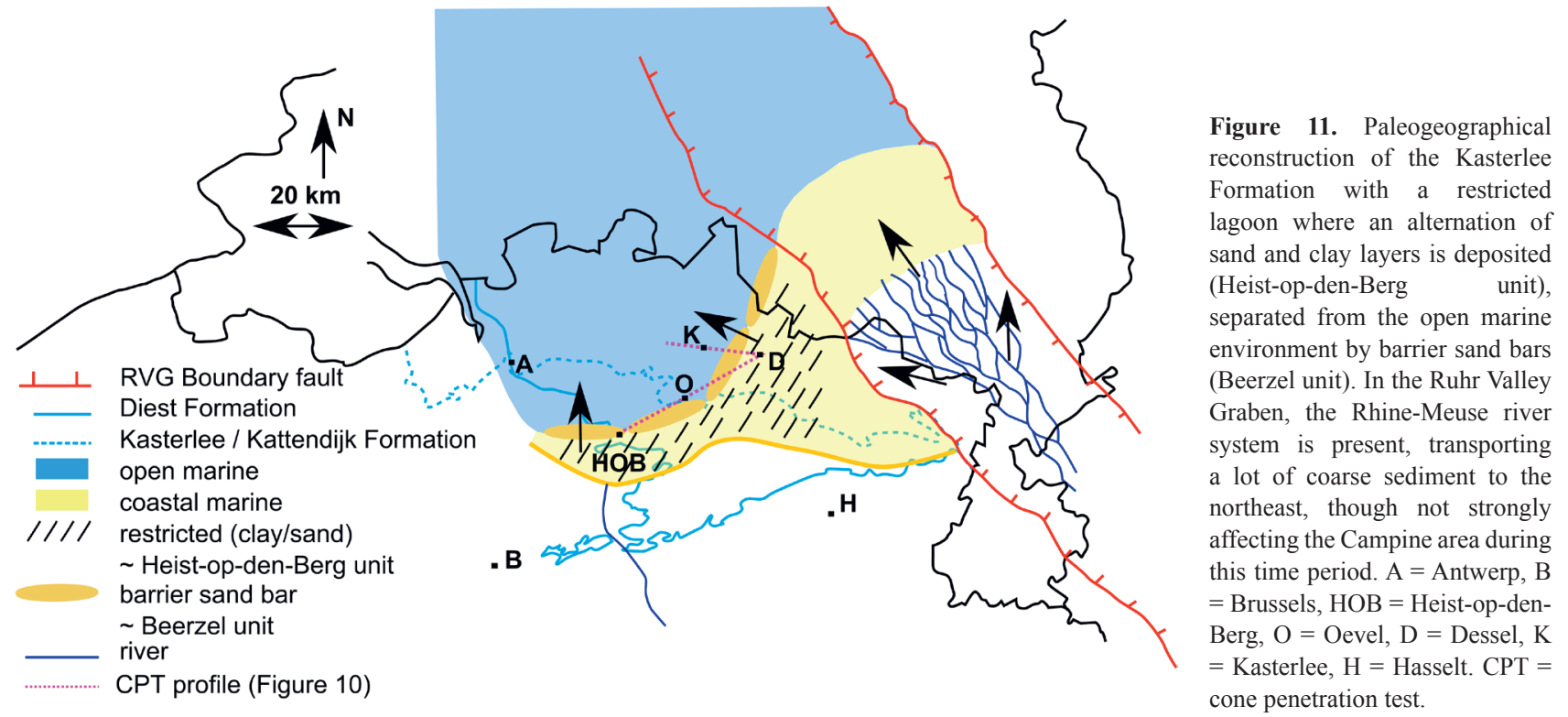

Sand of the type area could have evolved into the quartz-rich sand named Kasterlee-sensu-Gulinck or lower Mol unit as discussed in Vandenberghe et al. (2020, this volume), and as such correlates with the lower part of the Mol Formation according to the new interpretation of the lower Mol unit.

\section{Conclusions}

Based on the observations made in a temporary outcrop on top of the Heist-op-den-Berg hill and analysis of grain size and mineralogy of samples taken from this outcrop along a continuous section, different units of the Kasterlee Formation could be clearly defined. The Hallaar, Beerzel and Heist-op-den-Berg units can be distinguished based on their color, sedimentological characteristics, grain size distribution, glauconite content, clay content and mineralogy. Objective parameters were provided which make it possible to easily recognize these units in new outcrops or cores. A CPT profile shows that this subdivision is also relevant for applied geology and can be recognized to the north as well, at least towards the area of Olen.

As these units have very different characteristics which have been defined in detail, we propose to formally introduce the Hallaar, Beerzel, and Heist-op-den-Berg units as official members of the Kasterlee Formation, with the sunken lane next to the temporary outcrop described in the current paper as their stratotype.

Based on CPT profiles, the basal Hallaar unit and upper Heistop-den-Berg unit can be recognized consistently throughout the clayey Kasterlee unit. The middle Beerzel unit does not occur in the Retie-Dessel-Mol area in the northeast as the coastal barrier sand making up this unit was probably never deposited at that location. In the south, near the studied outcrop, and in the north, near the type area of the Kasterlee Formation, all units were deposited as a result of an overall progradation/regression. The depositional environment of the Kasterlee Formation is interpreted as consisting of a thin basal unit of reworked Diest sand (Hallaar unit), locally followed by lower shoreface sands, probably belonging to a prograding coastal barrier (Beerzel unit), and clayey lagoonal sediments (Heist-op-den-Berg unit). Over its transgressive surface, the Kasterlee Formation represents a normal regressive deposit built by the progradational, possibly stepped shift of two distinct depositional environments: a coastal barrier system and a non-tidal lagoon.

\section{Acknowledgements}

Our thanks to the site manager, Ignac Van Camp, of the company DCA nv for allowing us on the construction site. Many thanks to Professor Noël Vandenberghe for his comments on the preliminary version of the manuscript. Thanks as well to the reviewers, Dr Rik Houthuys and Dr Peter Stassen, for their constructive remarks and suggestions.

\section{References}

Adriaens, R., 2015. Neogene and Quaternary clay minerals in the southern North Sea. Unpublished Ph.D. Thesis, KU Leuven, Leuven, 272 p. https://limo.libis.be/primo-explore/fulldisplay?docid=LIRIAS193 $0587 \&$ context $=$ L\&vid $=$ Lirias\&search_scope $=$ Lirias\&tab $=$ default tab\&lang=en US\& fromSitemap $=1$, accessed 10/06/2020.

Deckers J., De Koninck R., Bos S., Broothaers M., Dirix K., Hambsch L., Lagrou, D., Lanckacker T., Matthijs, J., Rombaut B., Van Baelen K. \& Van Haren T., 2019. Geologisch (G3Dv3) en hydrogeologisch (H3D) 3D-lagenmodel van Vlaanderen - versie 3. Studie uitgevoerd in opdracht van het Vlaams Planbureau voor Omgeving (Departement Omgeving) en Vlaamse Milieumaatschappij. VITO-rapport 2018/ RMA/R/1569, $286 \mathrm{p}$.

Catuneanu, O., 2006. Principles of Sequence Stratigraphy. Elsevier, Oxford, $375 \mathrm{p}$.

de Heinzelin, J., 1963. Compte-rendu des excursions. In Symposium sur la stratigraphie du Néogène nordique, Gand, 1961. Mémoires de la Société belge de Géologie, de Paléontologie et d'Hydrologie, série in- $8^{\circ}, 6,183-225$.

Fobe, B., 1995. Lithologie en lithostratigrafie van de Formatie van Kasterlee (Plioceen van de Kempen). Natuurwetenschappelijk Tijdschrift, 75, 35-45.

Gulinck, M., 1963. Essai d'une carte géologique de la Campine. Etat de nos connaissances sur la nature des terrains néogènes recoupés par sondages. In Symposium sur la stratigraphie du Néogène nordique, Gand 1961. Mémoires de la Société belge de Géologie, de Paléontologie et d'Hydrologie, série in- $8^{\circ}$, 6, 30-39.

Gullentops, F., 1963. Etude de divers faciès quaternaires et tertiaires dans le Nord et 1'Est de la Belgique. Excursion O-P, 6e Congrès International de Sédimentologie 1963, Belgique et Pays-Bas, 20 p.

Gullentops, F. \& Huyghebaert, L., 1999. A profile through the Pliocene of Northern Kempen, Belgium. Aardkundige Mededelingen, 9, 191-202.

Halet, F., 1935. À propos des formations dites casterliennes des environs d'Herentals en Campine. Bulletin de la Société belge de Géologie, de Paléontologie et d'Hydrologie, 45, 290-297.

Houthuys, R., Adriaens, R., Goolaerts, S., Laga, P., Louwye, S., Matthijs, J., Vandenberghe, N., Verhaegen, J., 2020. The Diest Formation: review of insights from the last decades. Geologica Belgica, 23, 3-4, this volume. https://doi.org/10.20341/gb.2020.012

Jackson, M. L., 1975. Soil Chemical Analysis - Advanced course. $2^{\text {nd }}$ ed. Madison, Wisconsin, Published by the author.

Louwye, S., De Schepper, S., Laga, P. \& Vandenberghe, N., 2007. The Upper Miocene of the southern North Sea Basin (northern Belgium): a palaeoenvironmental and stratigraphical reconstruction using dinoflagellate cysts. Geological Magazine, 144, 33-52. https://doi. org/10.1017/S0016756806002627 
Matthijs, J., Lanckacker, T., De Koninck, R., Deckers, J., Lagrou, D., Broothaers, M., 2013. Geologisch 3D lagenmodel van Vlaanderen en het Brussels Hoofdstedelijk Gewest - versie 2, G3Dv2. Studie uitgevoerd door VITO in opdracht van de Vlaamse overheid, Departement Leefmilieu, Natuur en Energie, Afdeling Land en Bodembescherming, Ondergrond, Natuurlijke Rijkdommen, VITOrapport 2013/R/ETE/43, $21 \mathrm{p}$.

Reading, H.G., 1996. Sedimentary Environments: Processes, Facies and Stratigraphy. $3^{\text {rd }}$ ed. Blackwell, Oxford, $688 \mathrm{p}$.

Rogiers, B., Mallants, D., Batelaan, O., Gedeon, M., Huysmans, M. \& Dassargues, A., 2012. The usefulness of CPTs for deterministic, spatially heterogeneous, large-scale aquitard parameterization. Proceedings ModelCARE2011, Leipzig, Germany. International Association of Hydrological Sciences Publications, 355, 41-47.

Snellings, R., Machiels, L., Mertens, G. \& Elsen, J., 2010. Rietveld refinement strategy for quantitative phase analysis of partially amorphous zeolitized tuffaceous rocks. Geologica Belgica, 13, 183-196.

Schiltz, M., 2020. On the use of CPT's in stratigraphy; recent observations and some illustrative cases. Geologica Belgica, 23, 3-4, this volume. https://doi.org/10.20341/gb.2020.019

Schiltz, M., Vandenberghe, N. \& Gullentops, F., 1993. Toelichtingen bij de geologische kaart van België, Vlaams Gewest: kaartblad 24, Aarschot [1/50 000]. Belgische Geologische Dienst en Ministerie van de Vlaamse Gemeenschap, Bestuur Natuurlijke Rijkdommen en Energie, Brussel, 33 p.

Vandenberghe, N., Wouters, L., Schiltz, M., Beerten, K., Berwouts, I., Vos, K., Houthuys, R., Deckers, J., Louwye, S., Laga, P., Verhaegen, J., Adriaens, R., Dusar, M., 2020. The Kasterlee Formation and its relation with the Diest and Mol Formations in the Belgian Campine. Geologica Belgica, 23, 3-4, this volume. https://doi.org/10.20341/ gb. 2020.014

Van den Broeck, E., 1882. Diestien, Casterlien et Scaldisien. Note sur les dépôts lagunaires pliocènes d'Heyst-op-den-Berg et de Beersel et sur leur synchronisme dans la région d'Anvers. Annales de la Société royale Malacologique de Belgique, 17, CIII-CVIII.

Verhaegen, J., 2020. Stratigraphic discriminatory potential of heavy mineral analysis for the Neogene sediments of Belgium. Geologica Belgica, 23, 3-4, this volume. https://doi.org/10.20341/gb.2020.003

Verhaegen, J., Adriaens, R., Louwye, S., Vandenberghe, N., Vos, K., 2014. Sediment-petrological study supporting the presence of the Kasterlee Formation in the Heist-op-den-Berg and Beerzel hills, southern Antwerp Campine, Belgium. Geologica Belgica, 17, 323-332.

Zecchin, M., Catuneanu, O. \& Caffau, M., 2019. Wave-ravinement surfaces: Classification and key characteristics. Earth-Science Reviews, 188, 210-239. https://doi.org/10.1016/j.earscirev.2018.11.011 